\title{
Integrating Corporate Social Responsibility at the Start-up Level: Constraint or Catalyst for Opportunity Identification?
}

\author{
Vincent Lefebvre $^{1}$ \& Miruna Radu Lefebvre ${ }^{2}$ \\ ${ }^{1}$ ISC Paris School of Management, Paris, France \\ ${ }^{2}$ Audencia - PRES LUNAM, Nantes, France \\ Correspondence: Vincent Lefebvre, ISC Paris School of Management, 22, bd du Fort de Vaux, 75017 Paris, \\ France. Tel: 33-1-4053-9999. E-mail: vincent.lefebvre@iscparis.com
}

Received: December 12, 2011 Accepted: April 25, 2012 Online Published: July 1, 2012

doi: 10.5539/ibr.v5n7p17

URL: http://dx.doi.org/10.5539/ibr.v5n7p17

\begin{abstract}
This conceptual paper examines the issue of integrating CSR at the start-up level with the aim of increasing the firm's ability to identify new opportunities. Both a constraint and an occasion to strengthen the company's legitimacy and competitive advantage, CSR principles and practices are a key vehicle for opportunity identification and implementation. Historically, SMEs have contributed significantly to the improvement of existing products and services, and the creation of new ones. Grounding CSR in the strategy of enterprises at the start-up level is increasingly examined as an effective management tool with multiple benefits for opportunity identification. CSR may be promoted as a means of nurturing creativity and innovation at the start-up level and beyond, through pushing entrepreneurs to imagine new business models, to discover new raw materials, as well as to create new products and services so as to respond to both economic and social expectations.
\end{abstract}

Keywords: opportunity recognition, entrepreneurial opportunity, CSR, entrepreneurship, creativity

\section{Introduction}

Over the last decades, business organizations, regardless of their size or sector, have acknowledged an increasing pressure to comply with corporate social responsibility (CSR) imperatives and principles (Lepoutre \& Heene, 2006). From a practical standpoint, CSR is about how enterprises "manage their business processes to produce an overall positive impact on society” (Jenkins, 2009: 22). According to Dahlsrud (2006), there are at least 37 academic definitions of CSR emphasizing the main responsibility categories and issues, as well as the type of business responses "required", "expected" or "desired" so as to achieve more than economic performance purposes (Carroll, 1979, 1991; Carroll \& Shabana, 2010). Social responsibility in enterprises has been characterized in many ways, as "going beyond economic and legal requirements" (McGuire, 1963), "voluntary activities” (Manne \& Wallich, 1972), and a “concern for the broader social system” (Eells \& Walton, 1961) “giving way to social responsiveness” (Ackermann \& Bauer, 1976).

Derided first as a "joke, an oxymoron and a contradiction in terms" (Lyndenberg, 2005), CSR is today one of the most widely established guidelines of business organizations’ goal setting agendas (Lee, 2008). In the 1960s, Friedman (1962) passionately opposed the idea of CSR because he thought it imposed an unreasonable and expensive burden on shareholders. However, empirical studies have demonstrated that CSR positively impacts enterprise performance (Margolis \& Walsh, 2003). Indeed, according to McWilliams and colleagues (2006), CSR may be envisioned as a "strategic resource to be used to improve the bottom line performance of the corporation”, through increasing the firm's reputation and consumer loyalty (Kotler \& Lee, 2005), attracting responsible employees (Laszlo, 2003) and developing new markets (Porter \& Kramer, 2006).

SMEs represent $99 \%$ of all business and $66 \%$ of total employment in Europe, and generate half of the total value added in the European Union (Observatory of European SMEs, 2003). Traditionally, CSR academic literature predominantly investigated large-scale corporations, whereas little empirical research was conducted in small and medium-sized businesses and start-up contexts (Thompson \& Smith, 1991). The small business social responsibility research was actually hindered by the assumption that young firms genuinely lack the required time and/or resources to implement CSR processes (Lepoutre \& Heene, 2006). However, recent studies and reports indicate that SMEs and start-up companies may be "better positioned and equipped for socially 
responsible behavior than large firms" (ibid.: 258), because of their flexibility and their embeddedness in local community values and interests (European Commission, 2002). Moreover, start-ups and small businesses may benefit from CSR practices through maximizing corporate social opportunities described as "commercially viable activities which also advance environmental and social sustainability” (Grayson \& Hodges, 2004: 11). These new opportunities can be identified in three main domains: innovation in products and services, serving niche markets and elaborating new business models (Jenkins, 2009). This conceptual paper aims to examine the issue of integrating CSR categories and issues at the start-up level so as to increase the firm's ability to identify new opportunities and gain competitive advantage.

\section{Corporate Social Responsibility, Prerequisite and Vehicle of Competitive Advantage}

According to Porter (1985), competitive advantage stems from the company's “designing, producing, marketing, delivering and supporting” its products and services. In small businesses and start-up companies, CSR principles and practices may help entrepreneurs to add value to the company and differentiate from competitors (Jenkins, 2009). In an instrumental and integrative perspective, CSR assimilation into core business activities at the start-up level may be analyzed as an innovative dynamic capability (Teece et al., 1997) enabling companies to take advantage of new niche markets that incorporate social and/or environmental benefits (Jenkins, ibid.: 29). Rather than thinking about CSR as a costly externality, it may be beneficial for start-up companies to build it into the company's business strategy right from the beginning in order to prepare the favorable conditions to gaining competitive advantage from socially and environmentally responsible activities (Grayson \& Hodges, 2004).

\subsection{Brief History of CSR Theories}

Academic and professional concerns for CSR can be traced back to the period 1945-1960, but the CSR roots extend to before World War II (Acquier \& Gond, 2007). Howard R. Bowen's seminal work, "Social Responsibilities of the Businessman" (1953), shaped the future development of CSR literature through stressing the image of manager as public trustee with the obligation of providing corporate contribution and responsibility to society. During the 1960s and 1970s, the CSR literature expanded progressively along with broader social concerns about "corporate social responsiveness" (Frederick, 2008), that is the ability of a company "to achieve a responsive posture towards society" (Carroll \& Shabana, 2010: 88). In the 1970s, the focus was on corporate social performance, with an interest in assessing the outcomes of socially responsible initiatives (Wood, 1991). More empirical research was conducted during the 1980s, a decade committed to fostering business ethics principles and practices in organizations (Frederick, 2008). The rise of the "global corporate citizenship" was the culminating point of CSR research and business during the 1990s. Nowadays, CSR scholars and business actors emphasize the notions of sustainability and sustainable development.

According to Garriga and Melé (2004), CSR theories can be classified into four major categories: instrumental theories (economics issues), political theories (social power issues), integrative theories (social demands issues), and ethical theories (values issues).

1. Instrumental theories envisage CSR as a strategic tool to achieve profit (Friedman, 1970) through the maximization of shareholder value (Jensen \& Meckling, 1976), the achieving of competitive advantage (Porter \& Kramer, 2006), or the implementation of cause-related marketing (McWilliams \& Siegel, 2001).

2. Political theories see CSR as a means for companies to use their social power responsibly (Davis, 1960), through taking responsibility in the social arena and accepting social duties and rights. CSR is analyzed as an expression of the implicit social contract between business and society, with companies envisioned as "citizens" of the communities where they are operating (Andriof \& McIntosh, 2001).

3. Integrative theories view CSR as a way of responding to social demands in order to achieve social legitimacy and prestige through issues management (Sethi, 1975), public responsibility (Preston \& Post, 1981), stakeholder management (Ogden \& Watson, 1999), and corporate social performance management (Carroll, 1979).

4. Ethical theories consider CSR to be an ethical requirement for attaining a good society, through protecting human and labor rights (Cassel, 2001), promoting and implementing sustainable development measures (Van Marrewijk \& Were, 2003), and achieving common good (Velasquez, 1992).

\subsection{Corporate Social Performance and Competitive Advantage}

According to Carroll (1979), the most cited scholar of CSR integrative theories approach, corporate social performance consists in the integration of corporate social responsibility, corporate social responsiveness, and social issues. The first to highlight the idea that the companies' economic and social goals are not genuinely 
incompatible, Carroll (1979) explained that they all belong to the "total social responsibility" of business, which includes economic, legal, ethical and discretionary objectives to be met simultaneously (Lee, 2008: 60):

1. Economic responsibilities consist in the production of goods and services, which is the primary role of a firm;

2. Legal responsibilities consist in the fulfillment of legal requirements while assuming an economic function;

3. Ethical responsibilities consist in additional social missions that companies are expected to perform, even though they are ill defined and consequently difficult to identify and achieve;

4. Discretionary responsibilities consist in voluntary activities, such as philanthropic contributions, that are left up to the decision of the company.

These four kinds of responsibilities are linked to six major social issues: consumerism, environment, discrimination, product safety, occupational safety, and shareholders. In order to respond to these social issues, companies may choose from among three action strategies ranging from no response to proactive behavior. Wilson (1975) identified four potential business action strategies: reaction, defense, accommodation, and proaction, that Carroll (1979) integrated into his model of corporate performance.

The concern for profit and the concern for society are therefore reconciled in the "pyramid of corporate social responsibilities" conceptualized by Carroll (1991). Tensions among the company's four responsibilities are acknowledged, but the role of manager is that of deciding when and how to satisfy the various social and business obligations and expectations so as to strengthen both competitive advantage and the community's quality of life (Carroll, 1991: 40-42; Jenkins, 2009: 28). Within this perspective, corporate performance includes both financial and social dimensions (Paine, 2003), with business and society interwoven rather than completely separated entities (Wood, 1991). The assessment of corporate performance therefore includes customer satisfaction and retention, employee turnover, new products and services development, market growth and competitiveness (Brancato, 1995). Empirical studies demonstrated that there is a positive correlation between corporate social performance and financial performance (Carroll \& Shabana, 2010; Orlitzky et al., 2003). CSR-oriented enterprises have $18 \%$ higher profits, with CSR emerging as a commercial tool directly connected to brand value and competitive advantage (Gupta \& Sharma, 2009). Among the key benefits of integrating CSR principles and practices, scholars have emphasized the importance of cost savings, risk reduction, revenue increase, reputation, and access to capital (Been \& Bolton, 2011; Crane et al., 2008).

\subsection{Corporate Social Responsibility in Small Businesses and Start-up Companies}

The European Commission (2002) defined small businesses as those companies with fewer than fifty employees and a turnover or balance sheet that does not exceed ten million Euros. There are a very limited number of studies dealing with CSR in small businesses, probably because they are perceived as lacking sufficient time, resources and knowledge to implement social actions. Therefore, theories and methodologies have been developed in the context of large-scale corporations, more visible and accessible for research than small businesses (Lepoutre \& Heene, 2006: 262; Thompson \& Smith, 1991: 31). As a result, we know little about the meaning, the practices and the outcomes of CSR for small businesses and start-up companies (Jenkins, 2004; Lee, 2008). However, the existing findings indicate that the primary social responsibility of small businesses is customer satisfaction (Chrisman \& Archer, 1984). Also, entrepreneurs of small businesses and start-up companies stress the importance of product quality and employee responsibilities (ibid.). Although they seem to hold similar views about ethical, social and environmental principles as those in large-scale companies, entrepreneurs and small business managers tend to be very sensitive mostly to their immediate internal stakeholders, such as customers, employees and suppliers (Lahdesmaki, 2005).

Fairness, honesty, care about health and safety are perceived as characterizing the "responsible entrepreneur" (European Commission, 2002). According to Solymossy and Masters (2002), entrepreneurs are associated with specific personality traits, such as the internal locus of control (Shaver \& Scott, 1991), that increase the likelihood of responsible and ethical behavior. The general country value system, the specific sector expectations, as well as the pressures from local community and peers are the most important drivers for socially responsible actions in small businesses (Petts et al., 1999; Tilley, 2000). From a comparative standpoint, the country's level of welfare has an impact on CSR in small businesses and start-up companies (Matten \& Moon, 2008; Vives et al., 2005). The highest involvement was found in Northern European countries, such as Finland, Denmark, Iceland and Norway, whereas lower welfare countries, such as Spain and Greece showed a significantly lower involvement. However, according to Vyakarnam and colleagues (1997: 1633), industry norms and practices may exert a stronger influence on entrepreneurs' CSR decisions and actions than the national culture. 
Both a constraint and an occasion to strengthen the company's legitimacy and competitive advantage, CSR principles and practices are presented by Jenkins (2009) as a key vehicle for opportunity identification and implementation. Building on twenty-four case studies of UK small businesses, Jenkins (ibid.) demonstrated that CSR may help entrepreneurs to achieve added value and competitive advantage mostly by increasing the motivation and ability of small businesses and start-up managers "to seek opportunities in less traditional ways" while aiming to reconcile and take advantage of the articulation of economic and social requirements (ibid.: 24). Since competitiveness derives from the ability to build core competencies that allow companies to meet emerging and shifting market needs (Kurucz, Colbert \& Wheeler, 2008; Prahalad \& Hamel, 1990), the necessity of integrating CSR categories and issues at the start-up level is crucial as it allows entrepreneurs to structure the company's system and culture in a way that aligns "the business values, purpose and strategy with the social and economic needs of customers” (Grayson \& Hodges, 2004: 13).

\section{Corporate Social Responsibility, a Strategic Resource for Opportunity Identification at the Start-up Level}

Opportunities may be identified prior to the launching of a new business but may also occur throughout the life of the enterprise (Hills \& Shrader, 1998; Lindsay \& Craig, 2002). Grégoire, Barr and Shepherd (2010) observe that "opportunities arise from changes" in the macro-environment and the behavior of customers and enterprises, which make current practices, products and services suboptimal and therefore trigger future market adjustments, modifications and sometimes radical transformations. The development of new goods and services is of strategic importance for companies, as it is associated with wealth creation (Kirzner, 1997) and competitive advantage (Ahuja \& Kahila, 2004; Alvarez \& Busenitz, 2001; Shepherd \& DeTienne, 2005). Historically, SMEs have significantly contributed to the improvement of existing products and services, and the creation of new ones (Acs \& Audretsch, 1988; Lefebvre \& Lefebvre, 1993). Grounding CSR in the strategy of enterprises at the start-up level is increasingly examined as an effective management tool with multiple benefits for the opportunity identification processes within SMEs (Gupta \& Sharma, 2009; Jenkins, 2006, 2009).

\subsection{Entrepreneurial Opportunities: Nature, Sources and Types}

According to Shane and Venkataraman (2000: 218), entrepreneurship is "the scholarly examination of how, by whom, and with what effects opportunities to create future goods and services are discovered, evaluated, and exploited". Entrepreneurial opportunities represent "new ways of doing things" whereas other profit-oriented market opportunities consist in the optimization of existing means-ends relationships (Kirzner, 1973, 1997). The notion of "entrepreneurial opportunity" has been approached from a variety of theoretical perspectives, generating a wide range of different definitions (Hansen, Shrader \& Monllor, 2011), entrepreneurial opportunities being either conceptualized as an objective phenomenon distinct from the individual who identify them (Shane, 2003) or as a subjective experience endogenous to the individual who elaborate them (Sarason, Dean \& Dillard, 2006). After examining 56 articles dedicated to the topic of entrepreneurial opportunity in the last 19 years, Hansen, Shrader and Monllor (2011: 292) identified six main definitions coexisting in the entrepreneurial literature:

1. "The possibility of introducing a new product to the market at a profit" (Lee \& Venkataraman, 2006; Smith, Matthews, \& Schenkel, 2009);

2. "A situation in which entrepreneurs envision or create new means ends frameworks" (Sarason, Dean \& Dillard, 2006);

3. "An idea that has developed into a business form" (Anderson, 2000; Dimov, 2007);

4. “An entrepreneur's perception of a feasible means to obtain/achieve benefits” (Casson \& Wadeson, 2007; Krueger, 2000);

5. “An entrepreneur's ability to create a solution to a problem” (Chandler et al., 2003);

6. "The possibility to serve customers differently and better” (Alsos \& Kaikkonen, 2004).

Entrepreneurial opportunities are not restricted to new products and services, but also include new organizing methods and new raw materials (Smith, Matthews \& Schenkel, 2009). Alvarez and Barney (2010: 558) distinguish discovery opportunities, produced by "exogenous shocks to preexisting industries" (changes in technology, consumer behavior, demographics, etc.) and creation opportunities, shaped by entrepreneurs "through an enactment process".

Companys and McMullen (2007) acknowledged three major sources of entrepreneurial opportunities: differences in economic information, differences in the interpretation of environment information, and the access to 
information enabled by the specific location of social actors in network structures. These three different sources elicit different kinds of opportunities: economic opportunities, cultural cognitive opportunities, and sociopolitical opportunities (ibid.). Economic opportunities consist in technological and market opportunities, the first emerging in the form of product and raw materials innovations (Ahuja \& Kahila, 2004) whereas the second surface through the discovery of new customer needs or lead user innovations (Slater \& Narver, 1998). Cultural cognitive opportunities are producer and consumer opportunities, the first introducing new cultural meanings in existing cultural communities (Hargadon \& Douglas, 2001) whereas the second are initiated by customers who add new interpretations of existing products and services (Orlikowski, 2000). Sociopolitical opportunities may be network and political opportunities, the first resulting from social relations in existing networks (Rodan \& Galunic, 2004) whereas the second are generated by exogenous events, such as deregulations and wars that reconfigure network relations and therefore the entrepreneurs' access to information (Kogut \& Spicer, 2002).

\subsection{Opportunity Identification Processes: The Issue of Creativity}

The formulation of an opportunity comprises three major stages: opportunity search, opportunity recognition or identification, and opportunity evaluation (Hills, Lumpkin \& Singh, 1997). The opportunity search phase consists in the systematic or implicit scanning of the environment looking for potential sources of profit (Lindsay \& Craig, 2002). Entrepreneurship literature stresses three main processes of opportunity identification: accidental discovery in a moment of "insight" (Long \& McMullan, 1984), intentional discovery as the result of a systematic information search (Fiet, Piskounov \& Patel, 2005) and individual enactment emerging "from within the entrepreneur" (Sarasvathy, 2001). The first category of opportunities was labeled "tacit opportunities" while the second category was characterized as "codified opportunity" (Smith, Matthews \& Schenkel, 2009). Finally, opportunity evaluation involves the collection of additional information to verify the desirability and feasibility of the business idea (Lindsay \& Craig, 2002). Hansen, Shrader and Mollor (2011) highlight eight definitions of opportunity-related processes developed over the last decade:

1. "A cognitive process of recognizing an idea and transforming it into a business concept" (Lumpkin \& Lichtenstein, 2005);

2. “A process of scanning or being alert” (Casson \& Wadeson, 2007);

3. “A cognitive process of matching supply and demand” (Schindehutte, Morris \& Kocak, 2008);

4. "Perception of a felt need" (Haugh, 2007);

5. "A creative process of generating new alternatives” (Gaglio, 2004);

6. “A special case of problem-solving” (Harper, 2008);

7. "Perceiving a possibility to profitably create a new business or improve an existing one” (Craig \& Lindsey, 2001);

8. “A process of social construction within a window of time” (Fletcher, 2004).

These opportunity-related processes were examined as being closely linked to creativity (Dimov, 2007; Hansen \& Hills, 2004; Hills et al., 1997; Schumpeter, 1934; Winslow \& Solomon, 1993). According to Ray and Cardozo (1996: 12), entrepreneurial creativity is the ability to "rapidly recognize the association between problems and their purported solutions by identification of non-obvious associations and/or by reshaping or reforming available resources in a non-obvious way". Creative thinking is involved in cross-associations of pieces of experience, know-how and knowledge, enabling entrepreneurs to synthesize the various cues and information generated by their prior experience and their present environment (Simon, 1985; Ucbasaran, Westhead \& Wright, 2009). This is why opportunity identification is rarely a logical and linear progression, and rather articulates an often intuitive and deductive pathway, one idea leading to another (Lindsay \& Craig, 2002). Shackle (1961) emphasized entrepreneurial opportunities as "created perspectives". In this view, individuals may create opportunities "from almost nothing" (DeTienne \& Chandler, 2004), if they make use of their imagination appropriately.

\subsection{CSR: Additional Constraint or Creativity Driver?}

According to Kiran and Sharma (2011), the integration of CSR principles and practices at the start-up level positively affects the perceptions of investors, shareholders, suppliers, customers, and local communities. In our opinion, there are two main challenges for including CSR at the start-up level: the first concerns the opportunity identification processes, while the second is linked to the implementation of CSR in the business model, as well as in the management and operations activities of the company on a daily basis. Concerning the first challenge, we think CSR could play a favorable role during the opportunity identification phase, although it may be initially 
perceived as an additional constraint and cost for the start-up venture. Once the entrepreneur and his/her founding team became motivated and committed to incorporate CSR in the start-up venture, this will trigger awareness about different and new ways of doing business and making profit, thus providing competitive advantage (Tilley et al., 2003).

Evidence exists that this approach is highly beneficial for SMEs as it significantly contributes to attracting business partners and customers, while strengthening the company's reputation (Jenkins 2006, 2009). Spense and Rutherfoord (2000) highlight the existence of four different social perspectives in SMEs regarding CSR:

1. The profit maximization priority consists in focusing mainly on profit-making;

2. The subsistence priority consists in ensuring the long-term survival of the company;

3. The enlightened self-interest consists in involvement in social issues as a tactical tool to enhance business reputation;

4. The social priority consists in integrating social values and actions in the business strategy and structure.

CSR may be promoted as a means of nurturing creativity and innovation at the start-up level and beyond, through pushing entrepreneurs to imagine new ways of organizing activities (new business models), to identify new raw materials, as well as to create new products and services so as to respond to both economic and social expectations (Gupta \& Sharma, 2009). Opening oneself to multiple external stimuli so as to increase the "number of repertories available to compete" may be therefore an effective way of dealing with CSR principles and practices throughout the opportunity identification process (Epstein, 1996).

\section{Conclusion}

Schumpeter (1934) noticed that entrepreneurs create opportunities through combining already existing products, services or processes. Long and McMullan (1984) also envisioned opportunity identification as a creative structuring process, with Hills, Shrader and Lumpkin (1999) bringing empirical evidence to support this idea. This conceptual paper examined the issue of integrating CSR principles and practices at the start-up level so as to stimulate opportunity identification. Entrepreneurial literature indicates that CSR may be promoted at the start-up level and beyond as a means of nurturing creativity and innovation, through increasing the entrepreneurs' creativity and therefore their ability to elaborate new products, services, and business models.

Indeed, rather than thinking about CSR as a costly externality, start-up ventures may profitably try to integrate CSR in their strategy with a view to gaining competitive advantage on their markets, as evidence exists that CSR positively affects financial performance, customer retention and brand value. However, there are very few studies dealing with CSR in small businesses, and therefore we know little about the meaning, the practices and the outcomes of CSR in start-up companies and SMEs. Quantitative research could be developed to categorize SME's according to their CSR strategy in terms of social issues interest: are they focused mainly on consumerism, the environment, discrimination, product safety, occupational safety, or shareholders (Carroll, 1979)? Complementary research might be elaborated to evaluate the business action strategies SME's and start-up companies set up to deal with CSR issues: are they primarily deploying reactive, defensive, accommodation, or proactive behaviors (Wilson, 1975)? Additional empirical research is also needed to examine the nature and sources of opportunities identified by those SMEs that decided to integrate CSR principles at the start-up level. For instance, qualitative empirical research may be conducted to determine the type of business opportunities entrepreneurs detect where integrating CSR principles at the start-up level: are they mainly linked to products, services or to business models? Also, empirical research could be developed to study the main sources of entrepreneurial opportunities incorporating CSR principles: are they predominantly economic, cultural cognitive or sociopolitical opportunities (Companys \& McMullen, 2007)? Finally, one may usefully test the influence of CSR on opportunity identification processes both at the individual and firm level. Moreover, empirical comparisons of SMEs that decided to incorporate CSR at the start-up level or during the early-development phase could help us understand the strategic relevance of CSR as a structuring principle of new ventures.

\section{References}

Ackermann, R., \& Bauer, R. (1976). Corporate social performance: the modern dilemma. Reston: Reston Publishing Co.

Acquier, A., \& Gond, J.-P. (2007). Aux sources de la responsabilité sociale de l'entreprise: à la (re)découverte d'un ouvrage fondateur, Social responsibilities of the businessman, d'Howard Bowen. Revue Finance Contrôle Stratégie, 5-35. 
Acs, Z. J., \& Audretsch, D. B. (1988). Innovation and firm size in Manufacturing. Technovation, 7, 197-210. http://dx.doi.org/10.1016/0166-4972(88)90020-X

Ahuja, G., \& Kahila, R. (2004). Where do resources come from? The role of idiosyncratic situations. Strategic Management Journal, 25, 887-904. http://dx.doi.org/10.1002/smj.401

Alsos, G. A., \& Kaikkonen, V. (2004). Opportunities and prior knowledge: a study of experienced entrepreneurs. In S. A. Zahra, C. G. Brush, P. Davidsson et al. (Eds.), Frontiers of Entrepreneurship Research (pp. 300-314). Wellesley, MA: Boston College.

Alvarez, S. A., \& Barney, J. B. (2010). Entrepreneurship and Epistemology: The Philosophical Underpinnings of the Study of Entrepreneurial Opportunities. Academy of Management Annals, 4, 557-583. http://dx.doi.org/10.1080/19416520.2010.495521

Alvarez, S., \& Busenitz, L. (2001). The entrepreneurship of resource-based theory. Journal of Management, 27, 755-776.

Anderson, A. R. (2000). Paradox in the periphery: an entrepreneurial reconstruction? Entrepreneurship and Regional Development, 12(2), 91-109. http://dx.doi.org/10.1080/089856200283027

Andriof, J., \& McIntosh, M. (2001). Perspectives on corporate citizenship. Sheffield, UK: Greenleaf.

Been, S., \& Bolton, D. (2011). Key concepts in corporate social responsibility. London, UK: Sage. http://dx.doi.org/10.2139/ssrn.101660

Brancato, C. K. (1995). New corporate performance measures. New York: The Conference Board.

Carroll, A. B. (1979). A three-dimensional conceptual model of corporate social performance. Academy of Management Review, 4(4), 497-506.

Carroll, A. B. (1991). The pyramid of corporate social responsibility: Toward a moral management of $\begin{array}{lllll}\text { organizational stakeholders. } & \text { Business } & \text { Horizons, } & 34(4), 48 .\end{array}$ http://dx.doi.org/10.1016/0007-6813(91)90005-G

Carroll, A. B., \& Shabana, K. M. (2010). The business case for corporate social responsibility: a review of concepts, research and practice. International Journal of Management Reviews, 12(1), 85-105. http://dx.doi.org/10.1111/j.1468-2370.2009.00275.x

Cassel, D. (2001). Human rights business responsibilities in the global marketplace. Business Ethics Quarterly, 11(2), 261-274.

Casson, M., \& Wadeson, N. (2007). The discovery of opportunities: extending the economic theory of the entrepreneur. Small Business Economics, 28(4), 285-300. http://dx.doi.org/10.1007/sl 1187-006-9037-7

Chandler, G., DeTienne, D., \& Lyon, D. (2003). Outcome implications of opportunity recognition/discovery processes. In W. Bygrave, C. Brush, P. Davidsson et al. (Eds.), Frontiers of Entrepreneurship Research (pp. 398-409). Wellesley, MA: Babson College.

Chrisman, J. J., \& Archer, R. W. (1984). Small business social responsibility: some perceptions and insights. American Journal of Small Business, 9(2), 46-58.

Companys, Y. E., \& McMullen, J. S. (2007). Strategic entrepreneurs at work: the nature, discovery, and exploitation of entrepreneurial opportunities. Small Business Economics, 28(4), 301-322. http://dx.doi.org/10.1007/S11187-006-9034-X

Craig, J., \& Lindsay, N. (2001). Quantifying "gut feeling” in the opportunity recognition process. In W. Bygrave, E. Autio, C. Brush et al. (Eds.), Frontiers of Entrepreneurship Research (pp. 124-137). Wellesley, MA: Babson College.

Crane, A., McWilliams, A., Matten, D., Moon, J., \& Siegel, D. (Eds). (2008). Oxford Handbook of Corporate Social Responsibility. Oxford, UK: Oxford University Press.

Dahlsrud, A. (2006). How corporate social responsibility is defined: an analysis of 37 definitions. Corporate Social Responsibility and Environmental Management. retrieved September 2007 from http://www.csr-norway.no/papers/2007_dahlsrud_CSR.pdf. http://dx.doi.org/10.1002/csr.132

Davis, K. (1960). Can business afford to ignore social responsibilities? California Management Review, 2(3), 70-76.

DeTienne, D. R., \& Chandler, G. N. (2004). The role of gender in opportunity identification. Entrepreneurship Theory and Practice, 31(3), 365-386. http://dx.doi.org/10.1111/j.1540-6520.2007.00178.x 
Dimov, D. (2007). Beyond the single-person, single-insight attribution in understanding entrepreneurial $\begin{array}{llll}\text { opportunities. Entrepreneurship Theory and Practice, 31(5), } & \text { 713-731. }\end{array}$ http://dx.doi.org/10.1111/j.1540-6520.2007.00196.x

Eells, R., \& Walton, C. (1961). Conceptual foundations of business. Homewood, Ill.: Richard D. Irwin. http://dx.doi.org/10.1007/978-0-585-27624-3_7

Epstein, R. (1996). Cognition, creativity, and behavior: Selected essays. Westport, CT: Praeger.

European Commission. (2002). European SMEs and social and environmental responsibility. Brussels: Enterprise Publications.

Fiet, J., Piskounov, A., \& Patel, P. C. (2005). Still searching (systematically) for entrepreneurial discoveries. Small Business Economics, 25, 489-504. http://dx.doi.org/10.1007/s11187-004-2277-5

Fletcher, D. (2004). International entrepreneurship and the small business. Entrepreneurship and Regional Development, 16(4), 289-305.

Frederick, W. C. (2008). Corporate social responsibility: deep roots, flourishing growth, promising future. In A. Crane, McWilliams, A., Matten, D., Moon, J., \& Siegel, D. (Eds.), The Oxford Handbook of Corporate Social Responsibility (pp. 522-531). Oxford: Oxford University Press. http://dx.doi.org/10.1093/oxfordhb/9780199211593.003.0023

Friedman, M. (1962). Capitalism and Freedom. Chicago: The University of Chicago Press. http://dx.doi.org/10.7135/UPO9781843313595

Friedman, M. (1970). The social responsibility of business is to increase its profits. New York Times Magazine, September $13^{\text {th }}$, 32-33. http://dx.doi.org/10.1007/978-3-540-70818-6_14

Gaglio, C. M. (2004). The role of mental simulations and counterfactual thinking in the opportunity identification process. Entrepreneurship Theory and Practice, 28(6), 533-552. http://dx.doi.org/10.1111/j.1540-6520.2004.00063.x

Garriga, E., \& Melé, D. (2004). Corporate social responsibility theories: mapping the territory. Journal of Business Ethics, 53, 51-71. http://dx.doi.org/10.1023/B:BUSI.0000039399.90587.34

Grayson, D., \& Hodges, A. (2004). Corporate social opportunity! Seven steps to make corporate social responsibility work for your business. Sheffield: Greenleaf.

Grégoire, D. A., Barr, P. S., \& Shepherd, D. A. (2010). Cognitive processes of opportunity recognition: the role of structural alignment. Organization Science, 21(2), 413-431.

Gupta, S., \& Sharma, N. (2009). CSR - A business opportunity. The Indian Journal of Industrial Relations, 44(3), 386-401.

Hansen, D. J., \& Hills, G. E. (2004). Industry differences in opportunity recognition. Journal of Research in Marketing and Entrepreneurship, 6(1), 18-32. http://dx.doi.org/10.1108/14715200480001352

Hansen, D. J., Shrader, R., \& Monllor, J. (2011). Defragmenting definitions of entrepreneurial opportunity. $\begin{array}{llll}\text { Journal of Small Business } & \text { Management, }\end{array}$ http://dx.doi.org/10.1111/j.1540-627X.2011.00325.x

Hargadon, A. B., \& Douglas, J. Y. (2001). When innovations meet institutions: Edison and the design of the electric light. Administrative Science Quarterly, 46, 476-501.

Harper, D. (2008). Towards a Theory of Entrepreneurial Teams. Journal of Business Venturing, 23(6), 613-623. http://dx.doi.org/10.1016/j.bbr.2011.03.031

Haugh, H. (2007). New strategies for a sustainable society: the growing contribution of social entrepreneurship. Business Ethics Quarterly, 17(4), 743-749.

Hills, G., \& Shrader, R. (1998). Successful entrepreneurs' insights into opportunity recognition. In P. D. Reynolds, W. D. Bygrave, N. M. Carter et al. (Eds.), Frontiers of Entrepreneurship Research (pp. 30-43). Wellesley, MA: Babson College.

Hills, G., Lumpkin, G. T., \& Singh, R. P. (1997). Opportunity recognition: perceptions and behaviors of entrepreneurs. In P. D. Reynolds, W. D. Bygrave, S. Manigart et al. (Eds.), Frontiers of Entrepreneurship Research (pp. 168-182). Wellesley, MA: Babson College. 
Hills, G., Shrader, R., \& Lumpkin, G. T. (1999). Opportunity recognition as a creative process. In P. D. Reynolds, W. D. Bygrave, S. Manigart et al. (Eds.), Frontiers of Entrepreneurship Research (pp. 216-227). Wellesley, MA: Babson College.

Jenkins, H. (2004). A critique of conventional CSR theory: an SME perspective. Journal of General Management, 29(4), 37-57.

Jenkins, H. (2006). Small business champions for corporate social responsibility. Journal of Business Ethics, 67, 241-256. http://dx.doi.org/10.1007/sl0551-006-9182-6

Jenkins, H. (2009). A 'business opportunity' model of corporate social responsibility for small-and medium-sized enterprises. Business Ethics: A European Review, 18(1), 21-36. http://dx.doi.org/10.1111/j.1467-8608.2009.01546.x

Jensen, M. C., \& Meckling, W. (1976). Theory of the firm: Managerial behavior, agency cost, and capital structure. Journal of Financial Economics, 3, 305-360. http://dx.doi.org/10.2139/ssrn.94043

Kiran, R., \& Sharma, A. (2011). Corporate social responsibility: a corporate strategy for new business opportunities. Journal of International Business Ethics, 4(1), 10-17.

Kirzner, I. (1973). Competition and entrepreneurship. Chicago: University of Chicago Press.

Kirzner, I. (1997). Entrepreneurial discovery and the competitive market process: an Austrian approach. The Journal of Economic Literature, 35, 60-85.

Kogut, B., \& Spicer, A. (2002). Capital market development and mass privatization are logical contradictions: lessons from the Czech Republic and Russia. Industrial and Corporate Change, 11(1), 1-37. http://dx.doi.org/10.1093/icc/11.1.1

Kotler, P., \& Lee, N. (2005). Corporate social responsibility: doing the most good for your company and your cause. Hoboken, NJ: Wiley.

Krueger, N. (2000). The cognitive infrastructure of opportunity emergence. Entrepreneurship Theory and Practice, 25(3), 5-23.

Kurucz, E., Colbert, B., \& Wheeler, D. (2008). The business case for corporate social responsibility. In A. Crane, A. McWilliams, D. Matten, J. Moon \& D. Siegel (Eds.), The Oxford Handbook of Corporate Social Responsibility (pp. 83-112). Oxford: Oxford University Press. http://dx.doi.org/10.1093/oxfordhb/9780199211593.003.0004

Lahdesmaki, M. (2005). When ethic matters - interpreting the ethical discourse of small nature-based entrepreneurs. Journal of Business Ethics, 61(1), 55-68. http://dx.doi.org/10.1007/s10551-005-5333-4

Laszlo, C. (2003). The sustainable company: how to create lasting value through social and environmental performance. Washington: Island Press.

Lee, J.-H., \& Venkataraman, S. (2006). Aspirations, market offerings, and the pursuit of entrepreneurial opportunities. Journal of Business Venturing, 21(1), 107-123.

Lee, M.-D. P. (2008). A review of the theories of corporate social responsibility: its evolutionary path and the road ahead. International Journal of Management Reviews, 10(1), 53-73. http://dx.doi.org/10.1111/j.1468-2370.2007.00226.x

Lefebvre, L. A., \& Lefebvre, E. (1993). Competitive positioning and innovative efforts in SMEs. Small Business Economics, 5, 297-305. http://dx.doi.org/10.1007/BF01516250

Lepoutre, J., \& Heene, A. (2006). Investigating the impact of firm size on small business social responsibility: a critical review. Journal of Business Ethics, 67, 257-273. http://dx.doi.org/10.1007A10551-006-9183-5

Lindsay, N. J., \& Craig, J. (2002). A framework for understanding opportunity recognition. The Journal of Private Equity, Winter, 13-24. http://dx.doi.org/10.3905/jpe.2002.320030

Long, W., \& McMullan, W. (1984). Mapping the new venture opportunity identification process. In J. Hornaday, F. Tarpley Jr., J. Timmons \& K. H. Vesper (Eds.), Frontiers of Entrepreneurship Research (pp. 567-591). Wellesley, MA: Babson College.

Lumpkin, G. T., \& Lichtenstein, B. B. (2005). The role of organizational learning in the opportunity recognition $\begin{array}{llll}\text { process. Entrepreneurship Theory and } & \text { 451-472. }\end{array}$ http://dx.doi.org/10.1111/j.1540-6520.2005.00093.x 
Lyndenberg, S. D. (2005). Corporations and the public interest: guiding the invisible hand. San Francisco, CA: Berrett-Koehler.

Manne, H., \& Wallich, H. C. (1972). The modern corporation and social responsibility. Washington, DC: American Enterprise Institute for Public Policy Research.

Margolis, J. D., \& Walsh, J. P. (2003). Misery loves companies: rethinking social initiatives by business. Administrative Science Quarterly, 48, 268-305. http://dx.doi.org/10.2307/3556659

Matten, D., \& Moon, J. (2008). "Implicit” and "explicit” CSR: a conceptual framework for a comparative understanding of Corporate Social Responsibility. Academy of Management Review, 93(2), 404-426.

McGuire, J. W. (1963). Business and society. New York, NY: McGraw-Hill.

McWilliams, A., \& Siegel, D. (2001). Corporate social responsibility: a theory of the firm perspective. Academy of Management Review, 26(1), 117-127.

McWilliams, A., Siegel, D. S., \& Wright, P. M. (2006). Corporate social responsibility: strategic implications. Journal of Management Studies, 43, 1-18. http://dx.doi.org/10.1111/j.1467-6486.2006.00580.x

Ogden, S., \& Watson, R. (1999). Corporate performance and stakeholder management: balancing shareholder and customer interests in the UK privatized water industry. Academy of Management Journal, 42(5), 526-538.

Orlikowski, W. J. (2000). Using technology and constituting structures: a practice lens for studying technology in organizations. Organization Science, 11(4), 404-428. http://dx.doi.org/10.1287/orsc.11.4.404.1460

Orlitzky, S., Schmidt, F. L., \& Rynes, S. (2003). Corporate social and financial performance: a meta-analysis. Organization Studies, 24(3), 403-441. http://dx.doi.org/10.1177/0170840603024003910

Paine, L. S. (2003). Value shift: why companies must merge social and financial imperatives to achieve superior performance. New York, NY: McGraw-Hill.

Petts, J., Herd, A., Gerrard, S., \& Horne, C. (1999). The climate and culture of environmental compliance within $\begin{array}{lllll}\text { SMEs. Business Strategy and the Environment, } & \text { 8(1), }\end{array}$ http://dx.doi.org/10.1002/(SICI)1099-0836(199901/02)8:1<14::AID-BSE175>3.0.CO;2-4

Porter, M. E. (1985). Competitive advantage. New York, NY: Free Press.

Porter, M. E., \& Kramer, M. R. (2006). Strategy and society: the link between competitive advantage and Corporate Social Responsibility. Harvard Business Review, 78-92.

Prahalad, C. K., \& Hamel, G. (1990). The core competence of the corporation. Harvard Business Review, 3, 79-91.

Preston, I. E., \& Post, J. E. (1981). Private management and public policy. California Management Review, 23(3), 56-63.

Ray, S., \& Cardozo, R. N. (1996). Sensitivity and creativity in entrepreneurial opportunity recognition: a framework for empirical investigation. Global Entrepreneurship Research Conference.

Rodan, S., \& Galunic, C. (2004). More than network structure: how knowledge heterogeneity influences managerial performance and innovativeness. Strategic Management Journal, 25, 541-562. http://dx.doi.org/10.1002/smj.398

Sarason, Y., Dean, T., \& Dillard, J. F. (2006). Entrepreneurship at the nexus of individual and opportunity: A structuration view. Journal of Business Venturing, 21(3), 286-305. http://dx.doi.org/10.1016/j.jbusvent.2005.02.007

Sarasvathy, S. (2001). Causation and effectuation: Toward a theoretical shift from economic inevitability to entrepreneurial contingency. Academy of Management Review, 26(2), 243-263.

Schindehutte, M., Morris, M., \& Kocak, A. (2008). Understanding market-driving behavior: the role of entrepreneurship. Journal of Small Business Management, 46(1), 4-26. http://dx.doi.org/10.1111/j.1540-627X.2007.00228.x

Schumpeter, J. (1934). Capitalism, socialism, and democracy. New York, NY: Harper and Row.

Sethi, S. P. (1975). Dimensions of corporate social responsibility. California Management Review, 17(3), 58-64.

Shackle, G. L. S. (1961). Decision, order and time in human affairs. Cambridge, UK: Cambridge University Press. 
Shane, S. (2003). A general theory of entrepreneurship: the individual-opportunity nexus. Cheltenham, UK: Edward Elgar.

Shane, S., \& Venkataraman, S. (2000). The promise of entrepreneurship as a field of research. Academy of Management Review, 25(1), 217-226. http://dx.doi.org/10.5465/AMR.2000.2791611

Shaver, K. G., \& Scott, L. R. (1991). Person, process, and choice: the psychology of new venture creation. Entrepreneurship Theory and Practice, 16(2), 23-42.

Shepherd, D., \& DeTienne, D. (2005). Prior knowledge, potential financial reward and opportunity identification. Entrepreneurship Theory and Practice, 29(1), 91-112. http://dx.doi.org/10.1111/j.1540-6520.2005.00071.x

Simon, H. A. (1985). What we know about the creative process. In R. L. Kuhn (Ed.), Frontiers in Creative and Innovative Management (pp. 3-20). Cambridge, MA: Ballinger.

Slater, S. F., \& Narver, J. C. (1998). Customer-led and market-oriented: let's not confuse the two. Strategic Management Journal, 19(10), 1001-1006. http://dx.doi.org/10.1002/(SICI)1097-0266(199810)19:10<1001::AID-SMJ996>3.0.CO;2-4

Smith, B., Matthews, C., \& Schenkel, M. (2009). Differences in entrepreneurial opportunities: the role of tacitness and codification in opportunity identification. Journal of Small Business Management, 47(1), 38-58. http://dx.doi.org/10.1111/j.1540-627X.2008.00261.x

Solymossy, E., \& Masters, J. K. (2002). Ethics through an entrepreneurial lens: theory and observation. Journal of Business Ethics, 38, 227-241. http://dx.doi.org/10.1023/A:1015832123366

Spense, L. J., \& Rutherfoord, R. (2000). Social responsibility, profit maximization and the small firm owner manager. Journal of Small Business and Enterprise Development, 8(2), 126-139. http://dx.doi.org/10.1108/EUM0000000006818

Teece, D. J., Pisano, G., \& Shuen, A. (1997). Dynamic capabilities and strategic management. Strategic Management Journal, 509-533. http://dx.doi.org/10.1002/(SICI)1097-0266(199708)18:7<509::AID-SMJ882>3.0.CO;2-Z

Thompson, J. K., \& Smith, H. L. (1991). Social responsibility and small business: suggestions for research. Journal of Small Business Management, January, 30-44.

Tilley, F. (2000). Small firm environmental ethics: how deep do they go?. Business Ethics: A European Review, 9(1), 31-41. http://dx.doi.org/10.1111/1467-8608.00167

Tilley, F., Hooper, P., \& Walley, L. (2003). Sustainability and competitiveness: are there mutual advantages for SMEs?. In O. Jones \& F. Tilley (Eds.), Competitive Advantage in SMEs: Organizing for Innovation and Change (pp. 71-84). Chichester: John Wiley \& Sons Ltd.

Ucbasaran, D., Westhead, P., \& Wright, M. (2009). The extent and nature of opportunity identification by experienced entrepreneurs. Journal of Business Venturing, 24(2), 99-115. http://dx.doi.org/10.1016/j.jbusvent.2008.01.008

Van Marrewijk, M., \& Were, M. (2003). Multiple levels of corporate sustainability. Journal of Business Ethics, 44(2/3), 107-119.

Velasquez, M. (1992). International business, morality and the common good. Business Ethics Quarterly, 2(1), 27-40.

Vives, A., Corral, A., \& Isusi, I. (2005). Responsabilidad social de la empresa en las PyMEs de Latinoamérica. Washington, DC: Interamerican Development Bank.

Vyakarnam, S. B., Myers, A., \& Burnett, D. (1997). Towards an understanding of ethical behavior in small firms. Journal of Business Ethics, 16(5), 1625-1636. http://dx.doi.org/10.1023/A:1022452502299

Wilson, I. (1975). What one company is doing about today's demands on business. In G. A. Steiner (Ed.), Changing business-society interrelations. Los Angeles, CA: Graduate School of Management, UCLA.

Winslow, E. K., \& Solomon, G. T. (1993). Entrepreneurs: architects of innovation, paradigm pioneers and change. Journal of Creative Behavior, 27, 75-88. http://dx.doi.org/10.1002/j.2162-6057.1993.tb01391.x

Wood, D. L. (1991). Corporate social performance revisited. Academy of Management Review, 16(4), 691-718. 